\title{
OBSERVATIONS ON THE TREATMENT OF HUMAN GASTRIC AND COLONIC MUCUS WITH LYSOZYME ${ }^{1}$
}

\author{
By GEORGE B. JERZY GLASS, BETTY L. PUGH, WILLIAM J. GRACE, \\ AND STEWART WOLF \\ (From the Department of Medicine of the New York Hospital and the Cornell University \\ Medical College, New York, N. Y.)
}

(Received for publication June 6, 1949)

Interest has recently been focussed on the enzyme lysozyme as a result of the studies of Karl Meyer and his associates (1-4). They observed a much higher concentration of lysozyme in the stools of patients with ulcerative colitis than in those with normal colons or with other colonic disorders. In the gastric juice of subjects with peptic ulcer they found a less marked but apparently significant increase in lysozyme concentration above normal. From experimental observations in which was noted disappearance of the mucous coating in gastric pouches of dogs following the introduction of lysozyme these workers inferred that lysozyme attacked the protective layer of mucus investing the lining membrane of the stomach and colon. In experiments in vitro, however, they were unable to demonstrate such a lytic action on purified fractions of human gastric mucin. They did, however, induce experimentally gastrointestinal ulcerations in dogs by feeding them lysozyme in high concentration (1500 units or more per cc.). This concentration is higher than might be encountered in human pathologic processes (5).

The finding of increased lysozyme concentration in the stools of subjects with ulcerative colitis has been confirmed by Grossman (6) and by Grace and his associates (7). The latter demonstrated in subjects with ulcerative colitis that the lysozyme titre in the stools paralleled not only the clinical state of ulcerative colitis but also the state of relative security of the subject in his life situation. During periods of remission, when stools were normal and the subject was relatively relaxed and secure, lysozyme values were normal. In reaction to situations of significant personal conflict lysozyme concentration rose. When such increases in lysozyme concentration were sustained

1 Aided by grants from the Commonwealth Fund and the Estate of Lester N. Hofheimer. for three or four days an episode of exacerbation of colitis with bloody stools and tenesmus ensued.

In the gastric juice of subjects with peptic ulcer confirmation of Meyer's findings has been less clear cut. Grossman (6) induced ulcerations in the stomachs and colons of animals by local perfusion with a lysozyme solution in concentrations of approximately 2000 units per cc. (2 mgm. per cc.). This concentration is of course far above the physiologic range. He adduced, however, no histologic evidence of destruction of the mucus coating. Rather did the destructive process in many instances become evident first in the deeper layers of the mucosa. Grace (7) applied human tears containing 600 units of lysozyme per cc. to the exposed colonic mucous membrane of two fistulous human subjects and thus induced a weltlike localized lesion. The current studies were undertaken in an effort to settle the question whether or not lysozyme exerts a lytic action on human gastric and colonic mucus in vitro; that is, whether or not the gastric or colonic mucus or its constituents act as a substrate for the enzymatic action of lysozyme.

\section{GASTRIC MUCUS}

Sources

Specimens of gastric mucus were obtained from the following sources:

I. Visible gastric mucus obtained directly from the exposed mucosa of Tom, a fistulous subject who has been reported on in extenso elsewhere (8). Owing to a complete occlusion of this subject's esophagus, there was no possibility of contamination of these specimens with saliva or nasopharyngeal mucus. Seven separate specimens of the gastric mucus of Tom were, at various times, recovered from his acid gastric content under fasting conditions, and treated in the various ways described below.

II. Visible gastric mucus collected from alkaline secretions of stomachs during astroscopy of two individuals who continually displayed gastric anacidity. One of these subjects had undergone subtotal gastric resection for peptic ulcer. 
TABLE I

Effect of egg white lysozyme on human gastric mucus and its various fractions as measured by viscosimetric method of Meyer

\begin{tabular}{|c|c|c|c|c|c|}
\hline \multirow[b]{2}{*}{ Source of mucus* $\ldots \ldots \ldots \ldots \ldots \ldots \ldots \ldots \ldots \ldots \ldots \ldots \ldots$} & \multicolumn{5}{|c|}{ Relative viscosities } \\
\hline & $\mathbf{I}$ & $\mathbf{I}$ & III & IV & Control \\
\hline 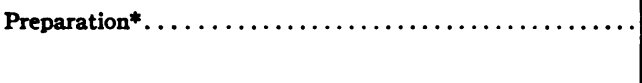 & $\mathrm{Ct}$ & Dt & $\mathrm{F}+$ & $\mathbf{F}$ & $\begin{array}{l}\text { Standard Micro- } \\
\text { coccus lysodeikticus } \\
\text { substrate }\end{array}$ \\
\hline $\begin{array}{l}\text { Before addition of lysozyme } \\
\text { After addition of lysozyme: } \\
\text { Immediately } \\
\text { Incubated for } 10 \mathrm{~min} \text {. at } 37^{\circ} \mathrm{C} \text {. } \\
\text { Incubated for } 20 \mathrm{~min} \text {. at } 37^{\circ} \mathrm{C} \text {. } \\
\text { Incubated for } 30 \mathrm{~min} \text {. at } 37^{\circ} \mathrm{C} \text {. } \\
\text { Incubated for one hr. at } 37^{\circ} \mathrm{C} \text {. } \\
\text { Incubated for two hrs. at } 37^{\circ} \mathrm{C} \text {. } \\
\text { Incubated for } 24 \mathrm{hrs} \text {. at } 37^{\circ} \mathrm{C} \text {. }\end{array}$ & $\begin{array}{l}3.01 \\
3.31 \\
3.20 \\
3.09 \\
3.00 \\
2.92 \\
3.06 \\
2.85\end{array}$ & $\begin{array}{r}2.30 \\
2.30 \\
2.32 \\
2.40 \\
2.42\end{array}$ & $\begin{array}{l}2.52 \\
2.22\end{array}$ & $\begin{array}{l}3.55 \\
3.55\end{array}$ & $\begin{array}{l}4.76 \\
2.50 \\
1.32\end{array}$ \\
\hline
\end{tabular}

* Numbers and letters correspond to those used in text when describing Sources and Preparations.

$\dagger$ Final concentration of egg white lysozyme in the mixture: substrate/lysozyme was in the preparation $\mathrm{C}=3000$ units per $1 \mathrm{cc}$., in the preparation $D=2500$ units per $1 \mathrm{cc}$, in the preparations $F=1200-1600$ units per $1 \mathrm{cc}$. of mixture.

III. Mucoprotein fraction of the dissolved gastric mucin from the pooled gastric juice of several individuals with duodenal ulcer, collected after insulin stimulation and separated by the method of Glass and Boyd (9).

IV. Mucoproteose fraction of dissolved gastric mucin separated by the method of the same authors (10) from the pooled gastric juice of several normal individuals.

Preparations of gastric mucus and dissolved mucin fractions

The specimens of gastric mucus were treated variously as follows:

A. No treatment; direct testing of the fresh material (I and II) after washing with McIlvaine buffer ( $\mathrm{pH} 5.5$ ) and homogenization by shaking.

B. Liquefaction of the fresh material (I and II) by incubation for one to three hours at $37^{\circ} \mathrm{C}$. after washing with McIlvaine buffer, homogenization by shaking, and clearing by centrifugation; testing of obtained viscous fluid material after adjusting its $\mathrm{pH}$ to $5.5-6.0$ by addition of $1 / 10$ normal $\mathrm{HCl}$ or $\mathrm{NaOH}$ depending upon mucus sample.

C. Precipitation with $1 \frac{1}{2}$ volume acetone of the visible gastric mucus (I) washed previously with acid-salt solution $(\mathrm{N} / 5 \mathrm{HCl}+0.9 \% \mathrm{NaCl})$; desiccation at $56^{\circ} \mathrm{C}$.; redissolving in $1 / 10$ normal $\mathrm{NaOH}$ and testing of the viscous solution after readjusting its $\mathrm{pH}$ to 5.5-6.0.

D. Precipitation with $1 \frac{1}{2}$ volume acetone of the visible gastric mucus (I) washed previously with acid-salt solution; desiccation at $56^{\circ} \mathrm{C}$.; redissolving in $1 / 10$ normal $\mathrm{NaOH}$; acidification to $\mathrm{pH} 5.0$ and extraction for one hour in electrical shaker with amyl alcohol-chloroform mixture; precipitation with zinc acetate at $\mathrm{pH} 7.0$; washing with water-acetone and acetone; desiccation at $37^{\circ} \mathrm{C}$.; pulverization; redissolving in dilute alkali and testing of obtained viscous fluid after readjusting its $\mathrm{pH}$ to 5.5 by addition of dilute $\mathrm{HCl}$.
E. Solution of visible gastric mucus (I) in one-half normal $\mathrm{NaOH}$, after washing with dilute $\mathrm{HCl}$ several times, and testing of the viscous solution after readjusting its $\mathrm{pH}$ to 6.0 by addition of dilute $\mathrm{HCl}$.

F. Mucoprotein and mucoproteose fraction of the dissolved mucin obtained from pooled gastric juices (III and

TABLE II

Effect of tears lysozyme on human gastric and colonic mucus as measured by volumetric method at constant temperature and constant time and speed of centrifugation

\begin{tabular}{|c|c|c|c|c|}
\hline \multirow[b]{2}{*}{ Source* } & \multicolumn{4}{|c|}{$\begin{array}{l}\text { Volumes of non-dissolved mucus } \\
\text { in per cent of initial values }\end{array}$} \\
\hline & \multicolumn{2}{|c|}{$\begin{array}{l}\text { Gastric mucus } \\
(I)^{*}\end{array}$} & \multicolumn{2}{|c|}{ Colonic mucus } \\
\hline \multirow[t]{2}{*}{ Preparations $†$} & \multicolumn{2}{|c|}{ A } & \multicolumn{2}{|c|}{$\mathbf{A}$} \\
\hline & \multicolumn{2}{|c|}{$\begin{array}{l}\text { In Mcllvaine } \\
\text { buffer }\end{array}$} & \multicolumn{2}{|c|}{$\begin{array}{l}\text { In McIlvaine } \\
\text { buffer }\end{array}$} \\
\hline $\begin{array}{l}\text { Before addition of tears, egg white } \\
\text { lysozyme or saline }\end{array}$ & 100 & 100 & 100 & 100 \\
\hline $\begin{array}{l}\text { After addition of tears, egg white } \\
\text { lysozyme or saline: } \\
\text { Immediately } \\
\text { After } 30 \mathrm{~min} \text {. at room tempera- } \\
\text { ture } \\
\text { After } 1 \mathrm{hr} \text {. at room temperature } \\
\text { After } 24 \mathrm{hrs} \text {. at room tempera- } \\
\text { ture } \\
\text { After additional incubation at } \\
37^{\circ} \mathrm{C} .: \\
\text { For four hrs. } \\
\text { For six hrs. } \\
\text { For } 24 \mathrm{hrs.} \\
\text { For } 48 \mathrm{hrs} \text {. }\end{array}$ & $\begin{array}{c}\begin{array}{c}\text { added } \\
\text { tears }\end{array} \\
100 \ddagger \\
106 \\
110 \\
110\end{array}$ & $\begin{array}{c}\text { added } \\
\text { saline } \\
100 \\
100 \\
100 \\
95\end{array}$ & $\begin{array}{c}\text { added egg } \\
\text { white lyso- } \\
\text { syme } \\
1008\end{array}$ & $\begin{array}{c}\begin{array}{c}\text { added } \\
\text { saline }\end{array} \\
100\end{array}$ \\
\hline
\end{tabular}

* Corresponds to number in text under Sources.

$\dagger$ Letters correspond to those used in text when describing Preparations.

$\mp$ Final concentration of tears lysozyme in this mixture was 100 units per $1 \mathrm{cc}$.

$\$$ Final concentration of egg white lysozyme in this mixture was 2000 units per $1 \mathrm{cc}$. 
IV) were redissolved in dilute $\mathrm{NaOH}$. The final $\mathrm{pH}$ of solution was brought to 6.5 by addition of dilute propionic acid; this caused an increase in viscosity of tested material which enabled the running of viscosimetric tests by Meyer's method. (In repeated control studies the addition of propionic acid in these concentrations to the mixture of egg white lysozyme and Micrococcus lysodeikticus substrate did not impair activity of tested egg white lysozyme.)

\section{Testing procedures and methods}

The mucus specimens and the viscous fluid preparations were exposed to lysozyme in various final concentrations, ranging from 50 to 3000 units per $1 \mathrm{cc}$. of mixture of lysozyme and mucus substrate. The lysozyme used was either in the form of purified egg white lysozyme which was generously supplied by Dr. Karl Meyer, or human tears, containing an average of 500 units of lysozyme per 1 cc. The testing procedures included:

a). Viscosimetric determination by the method of Meyer and Hahnel (11). Parallel checks for lysozyme activity were made against the standard Micrococcus lysodeikticus substrate (11).

b). Chemical analysis for the digestion products of mucus by determination of mucoproteose content after lysozyme action by above mentioned method $(9,10)$. c). Volumetric determination after centrifugation of the non-dissolved visible mucus before and after exposure to lysozyme. Centrifugation was carried out at $25^{\circ} \mathrm{C}$. for five minutes at $2000 \mathrm{rpm}$.

The determinations were made at varying intervals from immediately after aspiration of the gastric juice to 24 hours after incubation with lysozyme at $37^{\circ} \mathrm{C}$. Control determinations were made with distilled water, saline, McIlvaine buffer solution, crystallized Armour pepsin in solution, and native gastric juice containing lysozyme, added to tested mucus or its preparations.

Each series of tests on gastric and colonic mucus involved adding to the specimens a preparation of lysozyme and one or several control substances mentioned above.

Eight series of tests were performed on gastric mucus of which four were done on mucus from source $I$, two on mucus from source II, and one each on mucus from sources III and IV. The results are recorded in Figures 1-3 and Tables I and II. In addition to these tests the results of three series of tests on mucus from source I are recorded in Table III.

In addition to data reported here, seven series of tests were performed on gastric mucus from sources I-IV. These tests were not altogether complete, but the data they did yield were all in conformity with the results reported here.

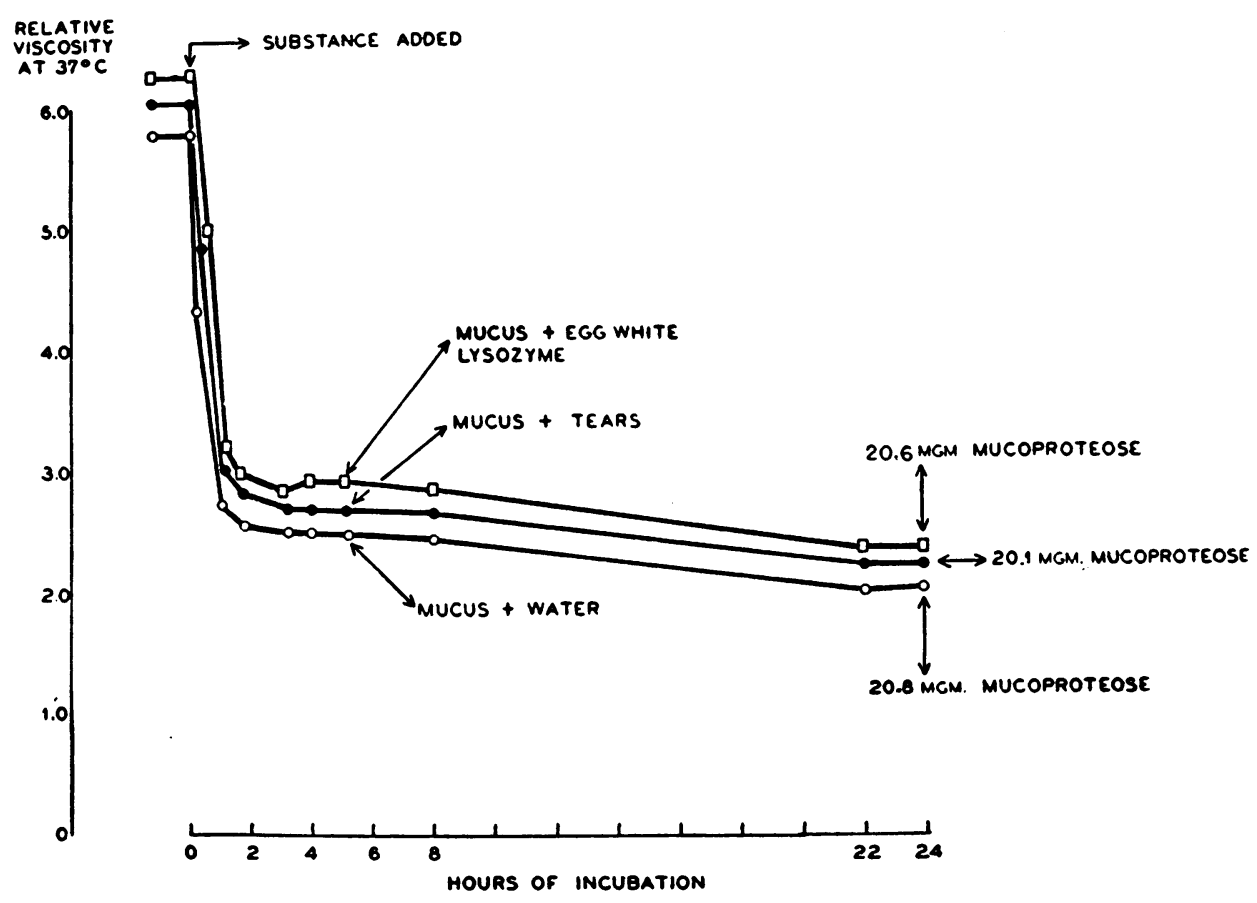

Fig. 1. Effect of Egg White Lysozyme and Tears on Viscosity of Gastric Mucus

Visible gastric mucus collected as described under Sources (I) from the exposed mucosa of Tom, and prepared as described under Preparations (B). To three samples of this preparation, 2 cc. each, were added respectively: 0.5 cc. distilled water, $0.5 \mathrm{cc}$. $30 \%$ solution of human tears in water, and $0.5 \mathrm{cc}$. of solution containing $1.5 \mathrm{mgm}$. egg white lysozyme. Incubation at $\mathrm{pH} 6.0$ and $37 \circ \mathrm{C}$. The mucoproteose content was determined after 24 hours of incubation. 


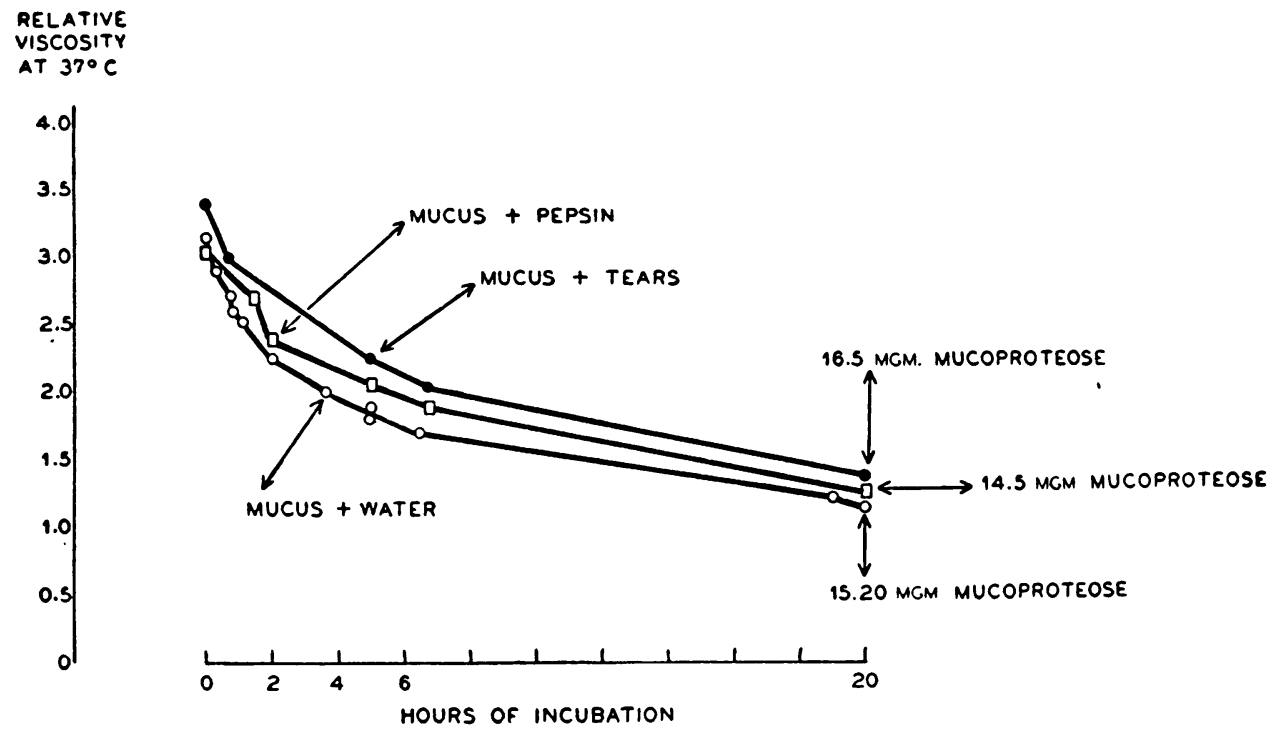

Fig. 2. Effect of Lysozyme in Human Tears on Viscosity of Gastric Mucus

Native gastric mucus collected as described under Sources (II) and prepared as described under Preparations (B). To three samples of this preparation, $2 \mathrm{cc}$. each, were added respectively: $0.5 \mathrm{cc}$. distilled water, $0.5 \mathrm{cc}$. solution containing $5 \mathrm{mgm}$. crystallized pepsin, and $0.5 \mathrm{cc}$. $50 \%$ solution of human tears in water. Incubation at $\mathrm{pH} 6.5$ and $37 \circ \mathrm{C}$. The mucoproteose content was determined after 24 hours of incubation.

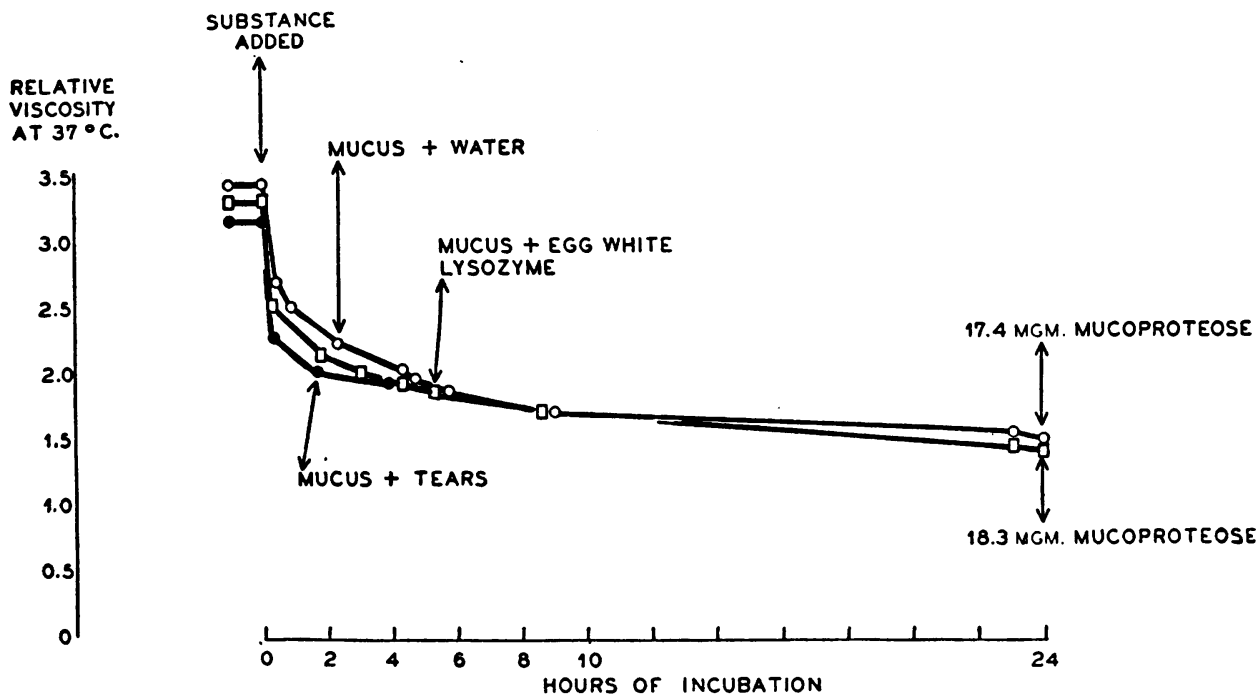

Fig. 3. Effect of Egg White Lysozyme and Tears on Viscosity of Gastric Mucus

Native gastric mucus collected as described under Sources (II) and prepared as described under Preparations (E). To three samples of this preparation, $2 \mathrm{cc}$. each, were added respectively : $0.5 \mathrm{cc}$. distilled water, $0.5 \mathrm{cc}$. solution containing $1.5 \mathrm{mgm}$. egg white lysozyme, and $0.5 \mathrm{cc}$. $30 \%$ solution of human tears in water. Incubation at $\mathrm{pH} 7.0$ and $37 \circ$ C. The mucoproteose content was determined after 24 hours of incubation.

\section{Results}

A. Effect of lysozyme on gastric mucus is shown in data listed in Tables I and II and Figures 1-3.
By none of the procedures outlined was it possible to demonstrate any mucolytic action of lysozyme on gastric mucus or its constituents even under optimal conditions for lysozyme activity. 
Table I shows the lack of effect of lysozyme on the relative viscosity of various preparations of gastric mucus. Table II shows the lack of dissolving effect of human tear lysozyme on gastric and colonic mucus as compared with controls. Figures 1-3 illustrate how nearly identical are the relative viscosity curves and the quantity of digestion products (mucoproteose) of gastric mucus exposed to lysozyme and to some of the control substances. It should be especially noted that the specimens tested included not only mucin derived from aspirated gastric juice but also the sticky mucinous coating removed directly from the gastric mucosa of Tom.

Comment: It will be noted from Table II and Figures 1-3 that gastric visible mucus at $\mathrm{pH}$ 6-7 undergoes a gradual autolytic process if incubated at $37^{\circ} \mathrm{C}$. for several hours. Since this process was neither enhanced nor accelerated by the addition of lysozyme (Figures 1-3) or pepsin (Figure 2) at this $\mathrm{pH}$, it seems reasonable to infer that lysozyme and pepsin do not play a role in splitting and dissolving gastric mucus at the neutral range of $\mathrm{pH}$, close to that of the native mucus. It may be postulated that another and as yet unidentified mucolytic agent (enzyme?) occurs in human gastric juice, which is contained in or adsorbed on to its visible mucus fraction and which may exert its mucolytic effect upon the gastric mucus at the neutral range of $\mathrm{pH}$. No data are yet available on the nature or significance of this agent (enzyme?).

\section{B. Effect of gastric mucus on lysozyme activity}

In order further to explore the possibility of interaction between gastric mucus and lysozyme, specimens of diluted egg white lysozyme in concentrations varying from 0.5 to 4.0 units per cc. were incubated for intervals varying between three and 24 hours at $37^{\circ} \mathrm{C}$., $\mathrm{pH}$ 5.5. Thereafter the activity of lysozyme in these mixtures was

TABLE III

Effect of mucus on the activity of the egg white lysozyme upon its bacterial substrate

\begin{tabular}{|c|c|c|c|c|c|}
\hline & & & & $\begin{array}{l}\text { Fir } \\
\text { concen } \\
\text { of lysoz } \\
\text { Meyer }\end{array}$ & $\begin{array}{l}\text { al } \\
\text { ration } \\
\text { yme in } \\
3 \text { units }\end{array}$ \\
\hline \multirow[t]{2}{*}{ Test 1} & $\begin{array}{l}\text { Egg white lysozyme (8 micro- } \\
\text { grams) in } 2 \mathrm{cc} \text {. of Mcllvaine } \\
\text { buffer (pH 5.5) }\end{array}$ & $\begin{array}{l}\text { Mixed and incubated for } \\
\text { three hrs. at } 37^{\circ} \mathrm{C} \text {. with: }\end{array}$ & $\begin{array}{l}0.3 \mathrm{cc} \text {. of same buffer } \\
1.0 \mathrm{cc} \text {. of same buffer average }\end{array}$ & $\begin{array}{l}3.50 \\
2.70\end{array}$ & 3.20 \\
\hline & The same & The same & $\begin{array}{l}0.3 \mathrm{cc} \text {. of mucus } \\
0.6 \mathrm{cc} . \text { of mucus } \\
1.0 \mathrm{cc} \text {. of mucus }\end{array}$ & $\begin{array}{l}2.80 \\
3.60 \\
3.20\end{array}$ & 3.20 \\
\hline \multirow[t]{2}{*}{ Test 2} & The same & $\begin{array}{l}\text { Mixed and incubated for } \\
24 \text { hrs. at } 37^{\circ} \mathrm{C} \text {. with: }\end{array}$ & $\begin{array}{l}0.3 \mathrm{cc} \text {. of same buffer } \\
0.6 \mathrm{cc} \text {. of same buffer } \\
1.0 \mathrm{cc} \text {. of same buffer } \\
\text { average }\end{array}$ & $\begin{array}{l}2.30 \\
1.60 \\
2.20\end{array}$ & 2.03 \\
\hline & The same & The same & $\begin{array}{l}0.3 \text { cc. of mucus* } \\
0.6 \mathrm{cc} \text {. of mucus } \\
1.0 \mathrm{cc} \text {. of mucus }\end{array}$ & $\begin{array}{l}4.40 \\
4.20 \\
3.50\end{array}$ & 4.03 \\
\hline \multirow[t]{2}{*}{ Test 3} & $\begin{array}{l}\text { Egg white lysozyme (1 micro- } \\
\text { gram) in } 2 \mathrm{cc} \text { of Mcllvaine } \\
\text { buffer ( } \mathrm{pH} 5.5 \text { ) }\end{array}$ & $\begin{array}{l}\text { Mixed and incubated for } \\
\text { three hrs. at } 37^{\circ} \mathrm{C} \text {. with: }\end{array}$ & $\begin{array}{l}0.1 \mathrm{cc} \text {. of same buffer } \\
0.2 \mathrm{cc} \text {. of same buffer } \\
0.5 \mathrm{cc} \text {. of same buffer } \\
\text { average }\end{array}$ & $\begin{array}{l}0.44 \\
0.44 \\
0.35\end{array}$ & 0.41 \\
\hline & The same & The same & $\begin{array}{l}0.2 \text { cc. of mucus } \dagger \\
0.4 \text { cc. of mucus }\end{array}$ & $\begin{array}{l}1.00 \\
1.00\end{array}$ & 1.00 \\
\hline
\end{tabular}

* Gastric mucus collected directly from Tom's stomach, washed several times with $1 / 10$ normal $\mathrm{HCl}$ and $\mathrm{Mc}$ Ilvaine buffer, homogenized by shaking, liquefied by incubation for two hours at $37^{\circ} \mathrm{C}$., cleared by centrifugation, its final $\mathrm{pH}$ being brought to 5.5 by addition of $1 / 10$ normal $\mathrm{HCl}$. The lysozyme content of this mucus preparation was less than 0.3 unit per $1 \mathrm{cc}$., as tested by Meyer's method.

$\dagger$ Gastric mucus collected directly from Tom's stomach, washed several times with $1 / 10$ normal $\mathrm{HCl}$ and $\mathrm{McIlvaine}$ buffer, dissolved in one-half normal $\mathrm{NaOH}$, cleared by centrifugation, its final $\mathrm{pH}$ being brought to 5.5 by addition of $1 / 10$ normal $\mathrm{HCl}$. The lysozyme content of this mucus preparation was 0.5 unit per $1 \mathrm{cc}$. 


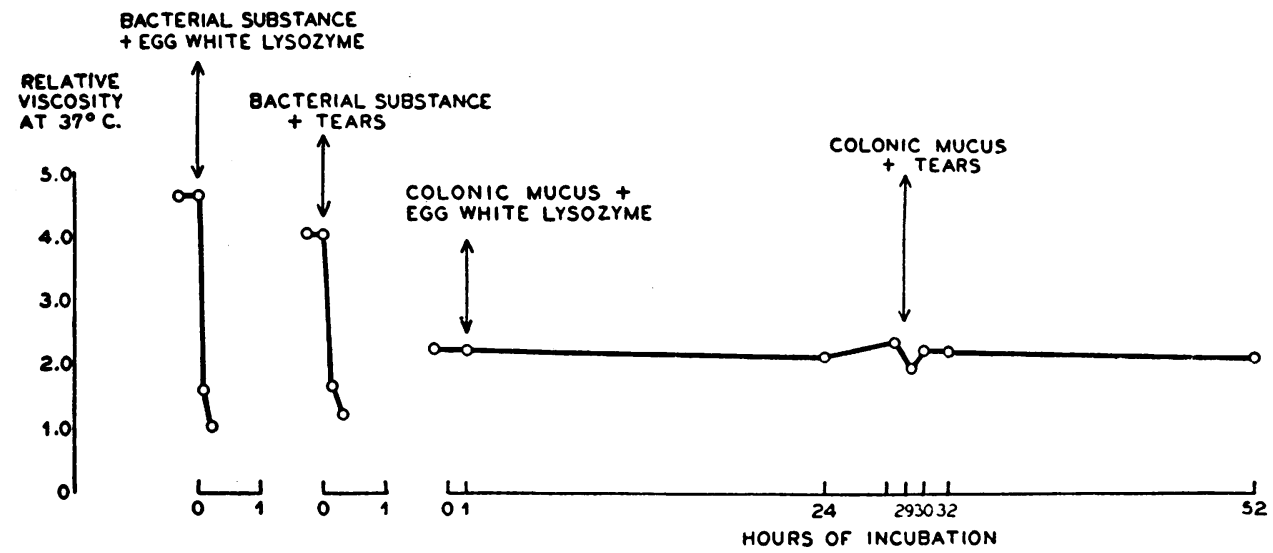

Fig. 4. Effect of Egg White Lysozyme and Tears on Viscosity of Colonic Mucus

Colonic mucus prepared as described under Preparations (E). To each of several mucus samples, $1 \mathrm{cc}$. each, were added $0.2 \mathrm{cc}$. saline solution containing 200 units of egg white lysozyme, and subsequently $0.1 \mathrm{cc}$. human tears (50 units lysozyme). Incubation at $\mathrm{pH} 7.0$ and $370 \mathrm{C}$. The curve represents averages of these determinations. As a control is shown the effect of the same egg white lysozyme and tears on the bacterial substance (substrate of Micrococcus lysodeikticus).

tested against controls (buffer solution) and against the standard Micrococcus lysodeikticus substrate. These data listed in Table III demonstrate that addition of gastric mucus does not decrease the activity of lysozyme upon its bacterial substrate (Micrococcus lysodeikticus). On the contrary some tests indicated a slight increase in lysozyme action after incubation for 24 hours with mucus which was greater than could be accounted for by the small amount of lysozyme present in the gastric mucus.

Comment: These observations establish further the lack of evidence of interaction between gastric mucus and lysozyme even under optimal $\mathrm{pH}$ and temperature conditions. If gastric mucus were in fact a substrate for lysozyme, one would have expected some of the lysozyme to have been "used up" during the incubation procedure.

\section{COLONIC MUCUS}

\section{Sources}

Colonic mucus was obtained directly from exposed loops of colon of two fistulous subjects described elsewhere in detail (12). One of these subjects had a normal colon. The other had ulcerative colitis.

\section{Preparations}

Samples from both subjects were treated by the methods described above under $A, C$, and $E$, for gastric mucus.

\section{Testing procedures}

These included viscosimetric determinations by the method of Meyer and Hahnel (11) of relative viscosity of colonic mucus preparations before and at varying intervals up to 24 hours after incubation with lysozyme at $37^{\circ} \mathrm{C}$.

Control determinations were made with water, saline and McIlvaine buffer. The activity of egg white or tears lysozyme was checked against the standard Micrococcus lysodeikticus substrate. Also as in the case of gastric mucus volumetric determination of non-dissolved mucus was made under standard conditions before and

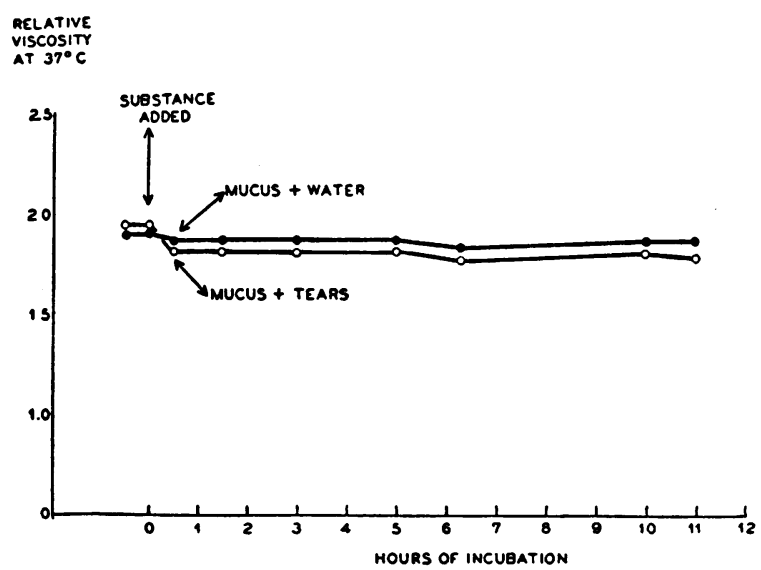

Fig. 5. Effect of Lysozyme in Human Tears on Viscosity of Colonic Mucus

Colonic mucus prepared as described under Preparations (C). To two samples, $2 \mathrm{cc}$. each, were added respectively 0.5 cc. tears (250 units lysozyme) and $0.5 \mathrm{cc}$. distilled water. Incubation at $\mathrm{pH} 5.5$ and $37^{\circ} \mathrm{C}$. 
after incubation with lysozyme for periods varying up to 24 hours.

Six series of tests were performed on colonic mucus. Four typical results are recorded in Table II and Figures 4-6.

\section{Results}

No lytic effect of lysozyme upon colonic mucus was demonstrated. Neither was any autolytic action observed. In Table II and Figures 4-6 are shown samples of the results of various testing procedures.

\section{Comment}

The approximately flat curves for serial determinations of viscosity and lack of gross evidence of liquefaction of colonic mucus at incubation at $37^{\circ} \mathrm{C}$. and $\mathrm{pH} 7.0$ indicate that native colonic mucus does not contain the mucolytic agent active in this range of $\mathrm{pH}$ which was detected in gastric mucus.

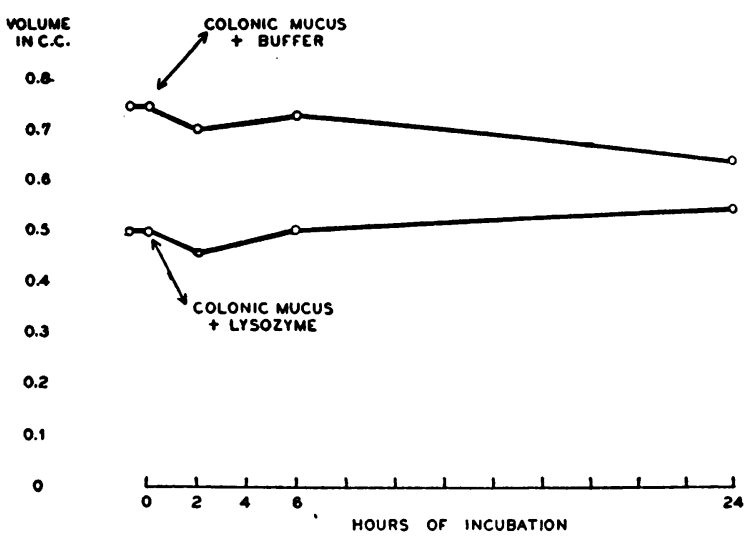

Fig. 6. Effect of Egg White Lysozyme on Liquefaction of Colonic Mucus

Colonic mucus prepared as described under Preparations (A). To each 0.5-0.75 cc. samples were added respectively 2 cc. of McIlvaine buffer ( $\mathrm{pH} 5.5$ ) and the same amount of this buffer containing $3.3 \mathrm{mgm}$. egg white lysozyme (4000 units). Incubation at $\mathrm{pH} 5.5$ and $37^{\circ} \mathrm{C}$. Volumetric detcrminations of non-liquefied mucus in graduated tubes at $2000 \mathrm{rpm}$ for five minutes and $25^{\circ} \mathrm{C}$. The values represent averages of several tests.

\section{DISCUSSION}

From these studies in vitro it would appear safe to conclude that lysozyme does not exert a lytic action on human gastric mucus. Thus it cannot play a role in clinical peptic ulcerative disease of the stomach by virtue of a mucolytic action. This inference receives strong support from the fact that in the relatively highly acid milieu of the gastric juice of the average patient with peptic ulcer lysozyme is inactive, even against the standard Micrococcus lysodeikticus substrate. Moreover, lysozyme has been shown to be inactivated by high concentrations of pepsin (1).

The lack of mucolytic effect of lysozyme in vitro on colonic mucus would also indicate that lysozyme cannot be considered a solvent agent for the mucus of the human colon.

The question of direct mucosal damage from lysozyme cannot be answered by the above data, but it should be noted that the only actual mucosal ulceration which has been produced experimentally required the feeding or infusion of a concentration of lysozyme far greater than that encountered in the human stomach or colon even under pathologic conditions. Further experiments are necessary to establish whether or not lysozyme in physiologic concentrations is actually capable of destroying or initiating destruction of mucosal cells.

One possible explanation of the striking correlation of elevated lysozyme concentration with ulcerations in ulcerative colitis is that the lysozyme may be elaborated as part of the biologic pattern of defense of the human organism directed chiefly against the possibility of bacterial invasion. The bacteriolytic properties of lysozyme were first recognized by Fleming et al. $(13,14)$ and are easily demonstrated. More recent data on the relation of lysozyme to bacteriophage would support this inference (15). Possibly, the increased secretion, or excretion of lysozyme into the colon during periods of emotional conflict preceding and accompanying an exacerbation of ulcerative colitis (7) may be related to the associated engorgement of the colonic mucosa.

\section{SUM MARY AND CONCLUSIONS}

Lysozyme from a human source (tears) and purified egg white lysozyme have been tested against various preparations of human gastric and colonic mucus by the viscosimetric method of Meyer and Hahnel and by chemical analyses for the products of mucin digestion (mucoproteose).

Neither whole gastric or colonic mucus from fistulous human subjects or its various preparations at optimal $\mathrm{pH}$ values, nor any of the purified 
constituents of gastric mucus were measurably dissolved or digested by egg white lysozyme or human tear lysozyme. This was true not only of mucin obtained from aspirated fluids but also of the mucinous coating removed directly from the mucous membrane of the stomach and colon. Conversely, contact of lysozyme with gastric mucus did not impair the activity of the lysozyme on its mucinous bacterial substrate (Micrococcus lysodeikticus).

In gastric mucus an autolytic process was noted at a neutral or slightly alkaline $\mathrm{pH}$. Since this action was not affected by addition of either lysozyme or pepsin it seems likely that it is due to the presence of another mucolytic agent (enzyme?) which acts at a neutral range of $\mathrm{pH}$ and which may be involved in the physiological process of mucolysis in the human stomach under these conditions.

These observations lead to the inference that whatever are the consequences of increased lysozyme secretion in ulcerative colitis, they do not include digestion of the protective layer of colonic mucus. Neither does lysozyme attack the protective mucous coating of the stomach, not contribute to the formation of peptic ulcer by virtue of its dissolving or splitting action on the gastric mucus.

\section{BIBLIOGRAPHY}

1. Meyer, K., Prudden, J. F., Lehman, W. L., and Steinberg, A., Lysozyme content of the stomach and its possible relationship to peptic ulcer. Proc. Soc. Exper. Biol. \& Med., 1947, 65, 220.

2. Meyer, K., Gellhorn, A., Prudden, J. F., Lehman, W. L., and Steinberg, A., Lysozyme in chronic ulcerative colitis. Proc. Soc. Exper. Biol. \& Med., 1947, 65, 221.

3. Meyer, K., Lysozyme, a mucolytic enzyme. Paper presented at a Seminar on Peptic Ulcer, Surgery Study Section, Nat. Inst. of Health, Bethesda, Md., Sept. 24, 1948.

4. Prudden, J. F., and Meyer, K., Lysozyme activity in peptic ulcer. Ibid. 5a. Meyer, K., Prudden, J. F., Lehman, W. L., and Steinberg, A., Lysozyme activity in ulcerative alimentary disease. I. Lysozyme in peptic ulcer. Am. J. Med., 1948, 5, 482.

b. Meyer, K., Gellhorn, A., Prudden, J. F., Lehman, W. L., and Steinberg, A., II. Lysozyme activity in chronic ulcerative colitis. Ibid, 496.

6a. Grossman, M. I., Gastroduodenal ulcers in dogs produced by continuous intragastric administration of acid and pepsin. Paper presented at a Seminar on Peptic Ulcer, Surgery Study Section, Nat. Inst. of of Health, Bethesda, Md., Sept. 24, 1948.

b. Grossman, M. I., and Wang, K. J., The action of lysozyme on gastrointestinal mucosa. In press.

7. Grace, W. J., Seton, P. H., Wolf, S., and Wolff, H. G., Studies on the human colon: I. Variations in concentration of lysozyme with life situation and emotional state. Am. J. M. Sc., 1949, 217, 241.

8. Wolf, S., and Wolff, H. G., Human Gastric Function: An Experimental Study of a Man and His Stomach. Oxford University Press, New York, 1947, Ed. 2.

9. Glass, G. B. Jerzy, and Boyd, L. J., The three main components of the human gastric mucin: dissolved mucoproteose, dissolved mucoprotein and mucoid of the gastric visible mucus. Part II. Method for separation and quantitative determination of each mucous component of the gastric content. Gastroenterology, 1949, 12, 835.

10. Glass, G. B. Jerzy, Boyd, L. J., Heisler, A., and Drekter, I. J., Studies on dissolved mucin of the gastric juice. III. Heterogeneity of the gastric dissolved mucin and its differentiation and separation into two fractions: dissolved mucoproteose and dissolved mucoprotein. Bull. N. Y. Med. Col., Flower and Fifth Ave. Hosps., 1948, 11, 8.

11. Meyer, K., and Hahnel, E., The estimation of lysozyme by a viscosimetric method. J. Biol. Chem., 1946, 163, 723.

12. Grace, W. J., Wolf, Stewart, and Wolff, H. G., The Human Colon. Paul B. Hoeber, Inc. In preparation.

13. Fleming, A., and Allison, V. D., Bacteriolytic substance ("lysozyme") found in secretions and tissues.. Brit. J. Exper. Path., 1922, 3, 252.

14. Fleming, A., On a remarkable bacteriolytic element found in tissues and secretions. Proc. Royal Society, London, 1927, 9, 306.

15. Krueger, A. P., Data to be published. 